\title{
Synergy in Halal Supply Chains
}

\author{
Marco Tieman*
}

\section{Introduction}

Integrity of halal supply chains is becoming an increasing concern for government and industry. There are a number of reasons for this. First, halal integrity issues are more likely to occur than before due to the increasing complexity of supply chains. Second, the complexity of today's supply chain, with a high percentage of imported ingredients, is making integrity issues harder to detect. Third, halal integrity issues once detected go viral on the internet, exposing the integrity of a country's halal system and the brand owner concerned. The neglect of halal requirements throughout the entire supply chain is gradually weakening consumer confidence in halal certified products.

Evidence supports that halal goes through an evolution from a Muslim company (purely based on a system of trust), halal product (product is halal certified), halal supply chain (a supply chain approach towards halal), to a halal value chain (halal is addressed throughout the entire value chain). ${ }^{1}$ In order to protect the halal integrity throughout the supply chain or value chain, a system of segregation and communication is required in order to provide a higher level of assurance to the Muslim consumer and protection for the brand owner. Segregation can be achieved by a system of physical segregation in transportation, storage and (sea/air/inland) terminals, to ensure that halal and non-halal goods flows are not combined on a load carrier and for (destination) Muslim countries not mixed in transport and storage. ${ }^{2}$ Segregation can come at a high cost, in particular non-Muslim countries where halal goods flows are small and not always easy to recognise, as the halal status of cargo is not always identified as such and is not communicated along the supply chain. Under the international halal standard for logistics (IHIAS 0100:2010) ${ }^{3}$, the code 'halal supply chain' has been recommended to be marked on labels and freight documents, and communicated as handling instruction through logistics and customs systems. This allows an easy identification of halal flows along the supply chain from producer, logistics service provider, trade, to retail and restaurants. However, until today the halal industry has not widely implemented halal logistics standards, as halal certification bodies have not extended halal requirements towards the supply chain. This has resulted in a halal industry where food safety (tayyib) requirements receive a 'supply chain approach' and halal requirements in most cases only a 'product approach'.

As the Holy Qur'an $(2: 168)$ puts halal and tayyib on equal footing, it would be logical to extend halal assurance towards the supply chain. To strive for 
excellence (ihsān) in halal supply chain management on the one hand and limit the impact in terms of cost as well as operational complexity for the halal industry on the other hand, the right balance (miz $\bar{a} n$ ) could be achieved through vertical and horizontal collaboration.

\section{Vertical Collaboration}

A supply chain is a network of parties that link the source to the point of consumer purchase. The horizontal supply chain structure refers to the number of tiers across the supply chain. The supply chain may be long with many tiers (many fast moving consumer good supply chains), or short with only a few tiers (like bulk supply chains). The vertical supply chain structure refers to the number of suppliers/customers represented within each tier. A company can have a narrow (few suppliers and/or customers) or wide (many suppliers and/or customers) vertical structure. ${ }^{4}$ As managing the entire supply chain is a complex task, there is tremendous potential to improve the performance of halal supply chains through improved coordination along the supply chain.

Effective vertical collaboration of halal supply chains can be achieved through (1) halal clusters and (2) halal supply chain orchestrators. Halal clusters are spatial clustering of halal production chains (halal food, cosmetics or pharmaceutical manufacturing) in an industrial park or economic zone, whereby a significant part of the supply chain is geographically positioned in a halal cluster, providing evident (1) logistic advantages (by shorter transportation times); (2) optimal use of by-products, including waste and energy; (3) increase capacity of cluster participants and innovation growth; and (4) stimulate new business formation that support innovation and expand the halal cluster. A halal society or institute can be established in the halal cluster to promote halal innovation projects, promote new Islamic economic activities and to reinforce the halal brand. Next to a local collaboration in the cluster, there are advantages to collaborate with halal clusters in other countries to facilitate access to supply of raw materials and (consumer) markets. Today there are halal park initiatives in Brunei (BioInnovation Corridor), China (Qinzhou), Malaysia (21 parks), and the United Kingdom (Birmingham and Norfolk). The halal parks in China and the United Kingdom are private sector initiatives. In Brunei they are government initiatives. Malaysia has a mix of parks run by local governments, government linked companies, and private sector. Thailand (Pattani) and the Philippines (Mindanao) are currently planning to develop halal parks.

A halal supply chain orchestrator assists in managing global halal supply chains according to the specification of the destination market and ensures that the integrity is maintained throughout the halal network. This orchestrator makes use of common halal distribution centres in key gateways, consolidation of 
transportation, and use of innovative logistics concepts (like a halal cargo box). ${ }^{5}$ This role can be fulfilled by a fourth-party logistics service provider: an integrator that assembles the resources, planning capabilities, and technology of its own organisation and other organisations to design, build, and run comprehensive supply chain solutions.

Vertical collaboration allows for:

1. effective halal supply chain assurance: reference to one international halal logistics standard (for example: IHIAS 0100:2010) and consistent communication of the halal status ('halal supply chain' code) throughout the supply chain;

2. standardisation of halal assets in a supply chain: from source to point of consumer purchase; and

3. supply chain optimisation: sharing demand data through the supply chain (facilitating a better customer response), reducing inventories, and better transportation planning.

\section{Horizontal Collaboration}

Collaboration between companies in the same industry, also known as horizontal collaboration, can take different forms in achieving synergy advantages in halal supply chains. Horizontal collaboration can be beneficial for manufacturers, retailers and restaurant chains. Collaboration can be facilitated through either (1) direct collaboration between different companies or through (2) an intermediary, such as a logistics service provider or trader. Direct collaboration among different companies can be achieved through four possible collaboration methods. First, there could be a dominant industry player, where smaller companies could use the halal assets or supplier contract (for example a contract with a transporter or logistics service provider) of the dominant player in the facilitation of the halal transportation and/or warehousing requirements of the other players. The dominant player has developed the halal assets or supplier contract based on his specifications only, whereas the others are using his assets or contract. It is a low cost method, but might lead to objections from the supplier. A second possibility is that transportation is facilitated by company A, warehousing facilitated by company B, and halal cargo boxes by company $\mathrm{C}$. The choice of which company will be used to facilitate which activity is based on the expertise, resources or volume. A third way is collaboration between companies in the same industry on project basis. This could be relevant to facilitate for example a joint supply from one country to Saudi Arabia to meet the food, cosmetics and medical requirements during the Hajj season. Another application could be a temporary 
collaboration between companies in the supply of humanitarian aid during a crisis situation, which requires an integrated supply chain management approach to effectively coordinate inter-agency performance, eliminate redundancies, and maximise efficiencies. ${ }^{6} \mathrm{~A}$ fourth method is an intensive collaboration on continuous basis between companies where many activities are done jointly. This could be applicable when companies are based in a halal cluster, in order to facilitate sourcing of halal raw materials (as well as other products and services) and distribution of halal goods.

An intermediary is able to consolidate halal goods flows for different companies that need domestic road transportation, cross border transport, air shipments, sea shipments, warehousing, and value added logistics (like repacking and customisation to certain Muslim markets). Here various companies can make use of the intermediary's expertise, global network and ability to consolidate halal flows for a more effective and efficient management of the various halal logistics requirements according to the destination market. Consolidation is one of the most important services offered by halal logistics service providers, where they really do add value to the halal industry.

Horizontal collaboration allows for:

1. sharing of information: 'halal supply chain' code, best practices in halal supply chain and value chain, and halal specifications [machine slaughter: yes/no; stunning: yes/no];

2. pooling of resources: outsourcing to a common (halal certified or compliant) logistics service provider, efforts, halal assets (for example a dedicated halal container); and

3. bundling of halal volumes: reducing transportation costs, improved segregation conditions.

\section{Conclusion and Recommendations}

Halal supply chain management is becoming important for consumer confidence in halal certified products. Halal requires a supply chain approach to provide a higher level of assurance to the Muslim consumer and better protection of halal brands. Halal supply chains are complex supply chains with vulnerabilities that need to be addressed through well organised, robust, effective and efficient halal supply chains.

New innovative solutions are needed for optimisation of halal supply chains that exploit collaboration, both vertically with supply chain partners and horizontally among companies in the same industry. Methods in vertical collaboration proposed are halal clusters and a halal supply chain orchestrator. Vertical 
collaboration allows for effective halal supply chain assurance, standardisation of halal assets in a halal supply chain, and supply chain optimisation. Possible methods in horizontal collaboration are direct collaboration models and collaboration through an intermediary. Horizontal collaboration allows for sharing of information, pooling of resources and bundling of halal volumes.

The application of vertical and horizontal collaboration concepts provides better control of halal supply chains from source to point of consumer purchase and increases consumer confidence in halal certified products. These vertical and horizontal collaboration concepts require a more advanced halal certification system (beyond product certification), expanding halal regulations along the supply chain. The halal certification body, which often is accredited by the government, therefore further enhances the (indirect) control of halal supply chains by governments. This should reduce the exposure of a country's halal system and brand owners. Governments are recommended to stimulate vertical and horizontal collaboration initiatives in the halal industry and the development of a more advanced halal standard, incorporating international halal standards, which support a supply chain approach to halal.

Industry pilots and case study research are needed to test the various collaboration concepts and provide practical solutions for the halal industry to optimise international halal supply chains. This supports the development of customer-driven supply chains that are better able to meet the diverse Muslim market requirements and to conform to a common halal standard throughout the supply chain from source to point of consumer purchase.

\section{Notes}

* Marco Tieman, the founder of LBB International (The Netherlands), a logistics consulting, research and supply chain management firm with offices today in Malaysia, Thailand, Indonesia and the Netherlands. He is currently a PhD candidate with Universiti Teknologi MARA Malaysia in Shah Alam, Selangor, Malaysia. He is the author of the book Halal SuperHighway: A Command \& Control Blueprint for Halal Supply Chains (Norderstedt, Germany: GRIN Verlag, 2011). He has published various articles on the topic of halāl logistics and supply chain management in both academic and professional journals. He is a frequent speaker on halāl logistics at conferences in Asia, Europe, and the Middle East. (Email: marco@lbbteams.com)

1. Marco Tieman, "The application of halal in supply chain management: in-depth interviews", Journal of Islamic Marketing 2, no. 2 (2011), 186-195.

2. Marco Tieman, Jack GAJ van der Vorst, and Maznah Che Ghazali, "Principles in halal supply chain management", Journal of Islamic Marketing 3, no. 3 (2012), 217-243.

3. IHI Alliance, ICCI-IHI Alliance Halal Standard: Logistics - IHIAS 0100:2010 [first edition] (Kuala Lumpur: International Halal Integrity Alliance, 2010). 
4. Douglas M. Lambert and Martha C. Cooper, "Issues in supply chain management", Industrial Marketing Management 29, no. 1 (2000): 65-83.

5. Marco Tieman, "Control of halal food chains", Islam and Civilisational Renewal 3, No. 3 (2012): 538-542.

6. Rolando Tomasini and Luk van Wassenhove, Humanitarian Logistics (London: Palgrave MacMillan, 2009). 